\title{
HAVING RIGHT AND BEING RIGHT.
}

\section{JULIET EVERTS ROBB.}

IS it obliquity of moral vision or is it only clumsiness of tongue that leads us to confound two so different concepts as those which lie behind our expressions "having a right" and "being right?" The Frenchman, with his more delicate and accurate linguistic instrument, feels a strong distinction between "J'ai le droit" and "J'ai raison," and knows how infinitely more important is "raison" than "droit." A large and growing contingent of Englishspeaking men and women are eliminating the higher moral meaning from the word "right" and using it only to denote privilege or defiance. Defense of the right of the individual to do with his life what he will, scorn of the idea that conduct is bound up with the past and with the future, or correlated with anything distinguishable from self, is widely prevalent. Especially is there demand for the repeal of all sex restrictions. "I have the right even to bear a child, -and no questions asked," says the unmarried woman. "I have the right to be childless for any reason that may seem good to me, or for no reason but that I choose it so," says the married egoist, male or female. Always the statement, "I have a right"-never the question, " $A m$ I right?" Modern fiction and drama are seething with this septic ferment; and one has only to be a bit of a sensitive to register its coursing through the veins of society.

The trained nurse attending a friend of my sister was asked by a young lady for instruction in some method of birth-control. Quite frankly she said, "I have as much right to sex-enjoyment as any married woman, but, of course, I must not have children."

A maiden confided to a friend of mine that she longed intensely for a child and thought she had every right to bear one. My friend, who is too sympathetic to deny anything greatly wished for, agreed with her and advised 
carrying out the idea. She saw no wrong in the principle of the thing.

Among my more or less near acquaintances are two men who have, each, after marrying and begetting children by one woman, become enamoured of another. In each case the wife has been forced to divorce the husband in order that he might-respectably-marry her successor. His children were left with their mother. These men are unconscious of offense: they do not know that mothers should not be required or allowed to rear their children alone: to them children are a mere incident-a sort of imposition which their wives put upon them and of which a grant of money clearly rids them.

Not long ago, after heated discourse to the effect that all social ills were due to legal marriage and marriage customs, a woman of better than average intelligence said to me, "The oftener the marriage law is flouted the sooner it will be done away with." (As who should say, "If enough people got roaring drunk at once there would be no more liquor regulation and everything would be thoroughly joyful.")

Of the many childless wives whom I know one has refused motherhood because of unwillingness to endure physical pain; another, a star in the theatrical firmament when I was young, because of the superior claim of her career. Once, in her early wedded life, this woman, by accident, became pregnant. The infant was still-born. I never heard her mention it, but her actor husband bewailed the loss of two weeks and a sum of money.

Curious persons who inquire in certain circles who and what Sylvia is are told that she is this or that by occupation and that she "lives with" Urban, or that she used to "live with" Urban but is now "living with" Astro. It is never said that she is the mistress of Urban or of Astro-that would imply that she had sold herself for money. Of this Sylvia is incapable. The people who "live together" form a pact of equals on a basis of mutual passion or congenial tastes. Either is free to leave it at the first moment of dislike. 
And now comes a professor of philosophy to say, on the pages of The InTernational Journal of ETHICs ${ }^{1}$, that "marriage is an end in itself." Here is another equivocation. What the professor really says is that sex intercourse, purified and perfumed by fastidiousness, is an end in itself. He treats it very gracefully as "a personal intimacy of a unique and precious kind" "replete with significance" and "making a rich contribution to the content of life," which having been "found desirable" should be "cultivated and extended." This in a paper on birth-control which is what the physicians in the hospitals for insane call the "exciting cause" of the present article. The advocate of the further cultivation and extension of the sex-relation would undoubtedly accord it the honor which a public avowal of intention implies, but his context shows that it is not marriage which he holds to be an end in itself. Marriage, in its universally accepted sense, is nothing if not a means. It is a safeguard to wife and child and has no other significance. To say that marriage-meaning the sex-relation -is an end in itself is to join hands with Urban and Sylvia.

Each of the individuals cited is the type of a group and these groups, differing somewhat in ultimate objects and in details of procedure, have in common the belief that in all that has to do with sex every human is a law unto himself. In a way one must agree with them. Every man has a right, in the sense in which they claim right, to be a criminal or a fool, or anything else that appeals to him-but are they right?

To be right is to be in harmony with that force, not ourselves yet inseparable from ourselves, by which we live even while we dispute its dictates. Human speech about this power must, necessarily, be figurative. Let it be clearly understood that the use of a name for it, printed with lower case or capital, is solely for purposes of easier diction. The superstitious ancients called the unknown power fate; the devout endow it with infallibility, but with human

${ }^{1}$ Birth-Control, by Warren Fite. This paper appeared in October, 1916, but rankles still in my memory. J. E. R. 
partiality, and call it God; the skeptical treat it with an assumption of patronage and call it nature. Since we must have a name, this seems the best to me, because it suggests neither a senseless automatism nor a blinding halo; but Nature, even thus personified, does not present to my mind a person, but a force, indefinable but integrally a part of consciousness. Commenting on the use of the word Nature as a philosophic term Dr. Tufts says, "The point is that you can prove almost anything from 'nature' and it is the distinctive characteristic of moral conduct not to accept standards from nature or from any other source but to weigh and measure and finally set up standards on the basis of intelligent choice." But if you can prove anything by nature you can also justify anything by choice. And what is the criterion of the intelligence of a choice? We can neither weigh nor measure without a previously fixed standard. To what can the choices of men be referred for judgment as to their intelligence if not to this something that is not themselves? Nature may not be synonymous with right, but what we know of Nature's ideals is certainly all that we know of right. Many things, indeed, may be proved-or seem to be proved-from Nature, but not the one thing that would put an end to this discussion. It cannot be proved that the universe is dead. There is, incontrovertibly, an incessantly functioning force to which opposition and hindrance and delay are as atmospheric friction to the meteor, imparting brilliance, - a force which, like the hope of Prometheus, "creates out of its own wreck the thing it contemplates." To aid this contemplated thing-so far as possible to prevent wreckage-this is, surely, the part of wisdom. Permit me then, as the easiest way of expressing my thought, to say that to be right is to be in harmony with Nature.

Be it admitted that the ways of Nature are mysterious, that she seems, oftentimes, a devious and a stumbling guide. She has, in the past, insistently impelled her humans to promiscuity; at this hour she is leading them just a little beyond polygamy-simultaneous polygamy, that is; conVol. XXX.-No. 2. 
secutive polygamy is still quite "good form"-but through the ages of ages she has held to one unmistakable and unchanging purpose: to bring forth a man able to balance justly and to choose wisely among her permissions-for Nature has no decalogue, only conditioned possibilitiesand so to perfect himself. Why she should wish to do this, why she follows her incomprehensible methods, we may not and we need not know. The answer to all our whys is simply, "It is so." When humanity shall have reached more nearly that perfection, perhaps-but that is another matter. Here and now we are occupied with what we can clearly see of Nature's design.

For this purpose sex was evolved and the potency of its spell is not a generous contribution to the jocundity of life but the measure of the determination not to be thwarted. There must be new being and ever new being. Save as they affect her aims Nature cares not at all for Sylvia's attachment to Urban or to Astro, or whether their preferences in cigarettes or interior decoration or even in the higher forms of literature and art agree, or whether he supplies her or denies her the sensations she "cannot live without," or for her intensity of "temperament," or for his "wonderful talent" for something or other. None of these things is an object in itself. The revelations and creations of the fine arts, the discoveries and achievements of science, the assiduous cultivation of body and mind, everything that enhances the healthy zest of life, is, of course, valuably contributive to the desired consummation: but this goal must never be lost from view. What Nature requires of Urban and Sylvia, of Jonathan and Maria, is children.

The regulation of productivity in accordance with other natural tendencies, physical and social, is unquestionably advisable - the prolificacy of earlier periods being no longer necessary-but this must be done in consultation, as it were, with Nature; as we prune and clip and feed and train our garden plants in order to obtain the finest, rather than the fullest, bloom. This is not rebellion against but 
alliance with Nature. Entirely to circumvent her design is to defeat our own most selfish ends, to fall short of fulfilment, to reduce our garden to colorless, perfumeless, fruitless failure. We are at liberty to do this. We may choose among various lines of conduct, in ignorance or in despite of Nature's conditions, or in awareness and in harmony with them: and we experience the inevitable consequences. The conditions are unappealable.

Dr. Fite says, in his interesting but very depressing paper (depression may be an "exciting cause"), "But I hold that the ways of Nature are authoritative for men only so far as they commend themselves to human intelligence in the satisfaction of humanly appreciable needs. . . . So far as the ways of Nature can be comprehended by us, it is both our right and our duty, as intelligent beings, to control them for our own uses."

But if our own uses be not also Nature's uses they are futile. Man has, indeed, outgrown the estate of a mere biological specimen; he has been admitted to confidence and to partnership with Nature. It is within his power to increase or to squander the firm's capital. If he waste his share he will be cast out and the business will go on without him. Nature must carry on: If we leave her only the Hun and the Bolshevik as material, why, so much the worse for us.

There is a test for all social theories and propositions: "Is this in line with Nature's effort; will it bring weal to the future generations?". Everything else is relative and transitory. Nothing else, though it may cover, for the moment, the visible earth and sky, is of any intrinsic or permanent importance. Dr. Fite says, again, "The social argument for fruitfulness and multiplication rests, in the last analysis, not upon the needs of a self-conscious humanity, but upon the external demands of a personified Nature:" to which it must be replied that only to a very superficially conscious humanity can the demands of Nature seem external.

What answer to these demands is made by those, for 
instance, who would abolish marriage? The free-unions are, almost always, intentionally childless. A child requires thought and care that might be spent in the pursuit of some dazzling will-o'-the-wisp. A child makes it more difficult to shift companionship with changing mood. The "liberated" ones, who claim obedience to the natural while contemning the social law, follow Nature while she beckons with alluring gesture and honeyed smile, but when she takes them by the hand to lead them over a bit of rugged road they draw back. They are by no means all gross voluptuaries, but they are all frank egoists. "I must live my own life" is their motto, and "my own life" means, in their mouths, unqualified self-indulgence. Their ideals are sensuous dreams. They see with the eyes of the body, not of the mind. Clear vision does not derive from dreams, but from active exercise in waking realities - as the creative brain is nourished not by alcohol but by bread.

What answer is being made by the woman who asserts that motherhood is honorable under any circumstances, who desires maternity but protests against the imposition of a ceremony-a "patter of words" -and the fetters of wifehood as the sine qua non of respectability? Society, she declares, is mistaken in supposing that a woman who gives birth to an unauthorized child is, necessarily, of coarse appetites and loose morality-ignoring the wide distance between the mother by unwelcome accident and the mother by her own volition. These women might seem to balance, were they given their way, the shirkers of maternity: but consider, for a moment, this latter-day proclamation of "woman's rights." Unmarried maternity involves, always, secrecy as to the child's father. Men do not willingly acknowledge illegitimate children. Their fierce sense of private ownership drives them to exact that their acknowledged offspring be mothered by their legal wives. A man can not be sure that the child of his paramour is also his. Speeches are being made, short stories and long novels are being written, to sustain the doctrine 
that a woman's will to maternity is authority enough and that the name of her infant's father concerns no one, not even the child. Mothers by their own election, it is said, are good mothers. So they may be, within the limits of their feminine capacities, but they are only partially conforming with Nature, since they are blind to the interest of the child whom they, not being wives, bring into the world unfathered.

A boy who does not know his father intimately, who does not feel that he is a precious care and a fond hope to his father, is injured, no matter how devoted a mother he may have. The girl who is exclusively mother-bred loses something essential-close acquaintance with a masculine mind, love and respect for mental maleness with no tincture of the sexual. There prevails a crippling lack of appreciation of the extent to which the absence of paternal influence is deleterious to children. Even in homes where they are more or less warmly welcomed they are, usually, 99 per cent the mother's. They are reared, from the cradle to the college, by women, and the girls are, for the most part, woman-taught in college. This is a double mistake: it deprives the fathers and defrauds the children.

If such a condition is found, even in the family, what of the progenitor of the half-orphan whose mother is unmarried? When I asked my friend who was carried away by the idea that motherhood needs no official sanction, but is self-justified, if she were willing to lend her husband for the project, she cried out, "O, no!" But the father of the little one would be some one's man-or he would be a free man who should stand, unless he were a contemptible coward, openly and gladly and sustainingly, beside the mother of his child.

And what of the child? We are always left, by the story-tellers, with these chance-conceived infants, who are to exalt unwedded maternity, in their rosy, dimpling babyhood: we are not allowed to follow them to adolescence and then to look into their tormented minds. When the son of the unringed mother begins to question, will she tell him 
the truth? Will she say, "I wanted a baby for my enjoyment: that should be enough for you: your father had his pleasure of me and we parted; you may look forward to the same privilege: so to deal with women is the meaning of manhood?" They do not so express themselves in the stories: they put on rings and call themselves widows.

Yet the defense by the unmarried woman of the right to bear is, in a way, a hopeful thing. It is the half-smothered protest of Nature against the "civilization" that threatens to neutralize even her magic of love. It is enheartening because it shows a savable vitality; it is pathetic because its demands are so short-sighted.

Indisputably there must be marriage-public, purposeful, legal. That stage of evolution is not yet in sight when the future of the race can be trusted to instinct or to enlightened principle. The element of chance is far too preponderant in our reproduction, as it is.

But why should I, who am of the present, trouble myself about the future of the race? Did the preceeding generations take thought for me? No. Yet behold the great and glorious creature that I am! Dr. Fite is not satisfied with any answer he can give himself to this kind of questioning. He says, "If the civilization of the future is to be merely a repetition of what it has come to now-and some wise persons tell us that it will never be different-then it seems to me clearly better that the race should not go on. . . . In any case it should be clear that a life process which consists only in a series of sacrifices-the present generation sacrificing itself for the next, and so on ad infinitum - is an absurd conclusion for a race of supposedly rational beings." So it is; but the absurdity lies not in the relation of one generation to the nextessential, unavoidable, not subject to human criticismbut in the use of the word "sacrifice." The situation calls for a stirring word like "realization." "Manhood begins when we have in any way made truce with Necessity: begins, even, when we have surrendered to Necessity, as the most part only do: but begins joyfully and hopefully 
only when we have reconciled ourselves to Necessity and thus, in reality, triumphed over it and felt that in Necessity we are free." 1 To deny the authority of Nature is not rational: as well seek to annul the motherhood of the woman who bore us: and Nature's decree, written in long pages of physical and social history, is Many more and always better children from the fit, fewer and much better children from the less fit-none at all only from the obviously unfit.

To remain, voluntarily, childless, to renounce the privilege and to refuse the responsibility of parenthood, for any reason but the altruistic one of unfitness, is to be not a quickening stream but a stagnant pool. No man, no woman, can reach full spiritual stature without mating and natural fruition. No life that was ever lived was worth while for the mere living of it. It is safe to say that no man arrives at sixty years, crowded though his days may have been with activities and successes and pleasures, who does not realize, perhaps with astonishment, that there has crept into his heart the knowledge that nothing is really worth living for but the children-his own, if he be so blessed; those of his neighbors in the palaces and in the slums, if he have been denied. I have heard it said by an old physician of national reputation, the father of a large family. I have heard a childless man whose books are known in all the schools of America declare, "I would give any success I am capable of winning to have had a daughter." I have heard a worn out harlot, who had sold her potential motherhood to the devil, first for pleasure then for money, lament in her age, "If only I had a child!" I have heard a well-beloved actress say to one of her company who marvelled at her enthusiasm, which never failed, even before a thin and unintelligent audience, "The public long ago lost all meaning to me. I play, always, for my children." Dr. Fite gives a half-hearted assent to this thought. He holds children to be "a source of intelligent

${ }^{1}$ Carlyle. 
satisfaction and an enrichment of personal life." No more than only this? With such a statement, save that I should greatly enlarge and intensify it, and with his advocacy of birth-control, but from a different view-point, I am in agreement. Most of what he says in great primer, as it were, I should say, if I said it at all, in nonpareil, and the thoughts which he accords a pale bourgeois I should utter in great primer. The idea that race-improvement is a distant thing with which we, in this present life, have no concern has surely been put to silence in these last four years. It has taken the rest of the world merely to check the one civilized nation which breeds conscientiously.

There is, however, more than a grain of justice in the indictment of our marriage customs by the feminists. Does any known ceremony denote the real object of marriage and bind to its promotive conditions? No and no. It is not enough to make the best of marriage-we should make our marriage the best. Legal marriage means exclusive sex-rights conferred by the woman in exchange for certain immunities. The man places himself under obligation to furnish her with shelter, food, clothing, amusement; to protect her reputation; to be responsible for her in every way; to value, moreover, her flesh so highly that he shall be forever satisfied therewith, no matter how greatly its charm may vary or diminish. She promises to be always responsive to him and cold to every other male. These crudities are overlaid with religious sentiment and romantic illusion, but, since the earliest record, this has been the intent of the contract, and the law, in this latest year of our Lord, still treats marriage as paid-for sex-monopoly. The one unfailing ground for divorce-in New York the only ground-is "infidelity," and everywhere the husband must support his wife whatever she may be or become - a spendthrift, a slattern, a shrew, a maniac. So long as he cannot prove that she is guilty of adultery he is liable for all her expenses. If she divorce him he must still pay, even if she marry a second husband, unless she 
waive her claim. He pays her for being his wife and for having been his wife, sometimes for having merely promised to be his wife, or for having thought that he meant to make her his wife. This is placing too high a premium on the carnal in woman.

Our civil and religious ceremonies, alike, bind the contracting parties for life and exact a promise to love each other so long as they both shall live. Instead of any inquiry into motives or qualifications the man and woman, who may have been brought together by animal appetite or by ambition or greed, or even by despair, are bidden to promise that they will love each other forever. How can any human being, even in the ecstasy of a first passionperhaps especially such a one-promise to love? The verb "to love" is defective: it has but two tenses-the present and the past. "I shall love?" Impossible! Still more so, "I will love." To swear it is perjury. One could as reliably promise that all the fruits of the union should be green-eyed girls. Love does last through long lives, but not because it was promised.

As to the religious aspect of marriage: the end held before the bride and groom by the episcopal rite, which is typical, is the attainment of eternal life for themselves, not the creation of new life; and they promise to serve each other, not to give the best that is theirs by inheritance and the best that may become theirs by earnest endeavor to the bearing and rearing of a family. Now personal immortality concerns the individual as an individual-it has nothing to do with marriage, nor has marriage with it.

If personal gratification and "cherishing" were, as is so generally believed, the object of marriage, there would be, truly, no call for public vows. Save for the well-being of their children and, under present conditions, the financial support of the wife, why should society care whether two were together or apart? Inherent in every legal enactment is the protection of the child-most especially in all sex legislation. Why not do, consciously and deliberately, and therefore much more thoroughly and expeditiously, 
that which we are really doing, under natural compulsion, but blindly and imperfectly and, often, painfully?

In the nuptial vows should be embodied the intention of parenthood, which involves the determination to remain together, in spite of whatever disappointment or dissatisfaction, with mutual willingness to adjust and compromise, until the children attain self-dependence. It may be said, with some reason, that the covenant to "live together after God's holy ordinance" implies the bearing of children; but the words are not definitive enough. They are understood as a recommendation to sex-fidelity, not to procreation. For some unfathomable reason the first is thought to be a proper exhortation while the second would offend a bride of to-day-let us hope not one of to-morrow.

Mothers and sisters and friends consult, endlessly and rapturously, with the prospective bride as to her trousseau, but how often is there premarital consideration of the girl's equipment for motherhood? We have, happily, passed the day when the very idea of sex lay, even between mother and daughter, as a kind of shameful secret: the young woman who consents to marriage knows what she is going to, but the natural result is comparatively unimportant. When her choice of a husband is announced to her parents they do not ask, "Is he sound and sane and magnanimous? Is it probable that his children will be worthy members of the human family?" Their questions are, instead, "Do you love him? Will he make you happy? Can he support you?" The prospective groom is more than likely to receive only felicitations on the prettiness and charm of his fiancée. The word "eugenics" floats about in the air from time to time, but it has never taken hold of people's minds. It excites ridicule rather than respect-and yet in it lies salvation. Our professor of philosophy says, "We call it prostitution to sacrifice the personal choice for pecuniary gain; from the personal standpoint, biology aside, it seems not less prostitution when the end is the propagation of the species. Certainly a proposal of marriage in these disinterested terms would seem horrible and grotesque." But 
biology cannot be set aside; call it what we will, the end is the propagation of the species; and with the added consideration of children personal choice, so far from being eliminated, becomes infinitely more precious and honorable. In any woman worthy to be chosen "I love and trust you -Will you be my wife and the mother of my sons and daughters?-I am sure that you will be a joy to me and a blessing to them" would certainly waken as glad response as the pleadings of hungry passion and the protestations of impossible devotion which have become conventional. To Isaac and Rebekah marriage meant a long line of inheritors of qualities and faiths and principles; to Reginald and Millicent it means only-each other.

This is the logical outcome of our purblind worship of "love." The apotheosis of sex-love is one of humanity's gravest errors. Sex-love is a tricksy sprite, a conjuror, not a deity. There is a god named Love at whose altar he who serves may gain supernal wisdom and boundless joy, but the best of us have wasted the time gathering posies and playing together outside instead of entering his temple; if we have passed within the doors we have mistaken the vestibule for the holy of holies: the worst of us have never even approached the sacred grove, but, in the stolen and dishonored name of love, have built altars to our senses and tended them with ill-omened rites.

Passion for passion's sake has always figured predominantly in poetry, drama and fiction. Formerly a thin veil of sweetness and delicacy was thrown about it: now that speech has violated the old prohibitions and found itself unrebuked the baseness of the common concept of love is daily revealed. The present tendency in literature, if not yet in conversation, is to glorify nakedness and abandoned sensuality. In a measure this is prophetic of health-like the draining of a sore- but literature has gone far too far in the development of its favorite theme. "Love is enough" is a pernicious falsehood. That he or she has "loved much" is not sufficient excuse for any and every dereliction, as it has been, in the code of the scribbler, for 
so long. Nothing more alarmingly betrays mental and moral disorder than the renunciation of self-control which the modernists are at pains to depict as a splendid movement toward liberty.

It is time that mankind should begin to try to grow above sexuality - to rule and use it, instead of being driven by it. For one who follows the novelists and dramatists and the reports in the daily press of idiotic and sinful marriages and foolish or scandalous divorces, it is hard to hope that human creatures will ever be able to restrain themselves within the bonds of reason and health-but it is only a matter of conviction. Man has disciplined other natural impulses. He no longer attacks the stranger who approaches him; he no longer eats whenever his eye lights upon food-because he has discovered that personal happiness is enhanced by fraternal relations with his fellows and by temperance in diet. In this other matter we are not only individually self-indulgent to an unsafe degree, we are a generation of panders; if not through deliberate action at least through toleration. By every public and shameless means, by licentiousness pictured on bill-boards and "movie" screens and enacted in theaters, by over-emphasized passion in the greater number of stories, by our dress, by an almost universal sympathy-ranging from jocose to sentimental -with any excess that calls itself "love," we keep the consciousness of sex poignantly alive in our young people -often to the exclusion of everything else.

And we do next to nothing to counteract these influences. In the schools the young are trained to mechanical efficiency, something of patriotism and something of civic spirit is recommended: on the subject of parenthood the faculties are mute. Mere prohibition is never effective, warning is wasted breath: unless we cultivate the sentiment of fatherhood and motherhood, unless we make the better thing seem the more delightful thing, we labor in vain. We must make the greater need "humanly appreciable"; there is no urgency about the "cultivation and extension" of the lesser. The profitable use and enjoyment of love is a mat- 
ter of slow education and, therefore, the immediate affair of all teachers, public and private; very particularly of authors, editors, playwrights and preachers - and, with them, of each one of us who compose the public which they address.

We must open the eyes of our young people, not to pathological horrors - that is not helpful teaching - but to the true and beautiful significance of love as the means to a noble and joyous end. Under good conditions love is a fragrant blossom, the precursor of delectable fruit: we are letting it degenerate into a noxious weed. There is a strong movement toward what is termed "enlightenment" of the young, but so far as I have observed it is followed by increase of darkness. Such light is too lurid to reveal truth. Can we not make youth to know-rightly? It is most apt in learning so much of the subject as is profitlessor worse. We must bind the young to life by strong realities, instead of letting them drift and blunder about in the mists of imagination, goaded by pangs which we take pains to sharpen for them. We should help them to think and to act as human beings-not merely as possible "lovers"-foster in them not the sickly, emotional selfconsciousness that drools, "I live for love, I live for love, I live for love, for love I die"-but the spirit that sings, "And when Italy's made, for what end is it done if we have not a son?"

When only the generations so reared survive there will be a different marriage vow and better conditions of wedded life. Not all will be parents, perhaps, but those who are not will think of childlessness as a misfortune. Women will realize anew the old truth, which the daughters of to-day, preoccupied with their extraordinary achievements in hitherto untried fields, appear to have forgotten: that there is nothing in this world braver or finer or more romantic than motherhood. There will be no unmarried mothers because all women will know that, while every woman has, theoretically, the right to motherhood, no woman is right who bears a child under any but the best auspicies for the 
child, and that these include the support and personal influence of a father: because, moreover, all men will know that he who is not the agent of progress becomes a cause of retrogression-that he who avoids fatherhood for the sake of his own ease and pleasure is like a track athlete whom conceit of his excellent body has made mad and whose silly feet lift him up and down, up and down, but never carry him forward, and who finally falls, to become dust under the feet of more faithful runners.

There is no danger of killing glamour and making life a sandy desert. Nature will see to it that her witchery does not go stale. Being right does not imply a neutral submission to sodden duty and the death of personal ambition - a cold, gray selflessness. On the contrary, it means an irresistible reason for the utmost possible acquirement of knowledge and power and the most assiduous cultivation of gifts. It means an infinite, elastic expansion instead of a hard and brittle intensification of happiness; not the "sacrifice" of each generation to the next and so on forevermore, but the possession by each generation not only of its own experience but of all the eternities.

Juliet Everts RobB.

New York. 